\title{
About the editors
}

Paul Sparrow is Emeritus Professor of International HRM at Lancaster University Management School and was Director of the Centre for Performance-led HR from 2006 to 2016. In 2016 he was awarded the USA's Society for HRM Michael R. Losey Award for lifetime achievement in human resource research and research contributions that impact the HR management field. He is regularly voted amongst the Most Influential HR Thinkers by Human Resources magazine, listed from 2008 to 2012 and 2014-2016. His research interests include crosscultural and international HRM, HR strategy and the employment relationship. He has several writing collaborations from which his latest books are on: Globalizing HRM (Routledge, 2004); Strategic Talent Management (Cambridge University Press, 2015); Do We Need HR? (Palgrave Macmillan, 2015); International HRM: Contemporary HR Issues in Europe (Routledge, 2016); and Human Resource Management, Innovation and Performance (AIAA, 2016).

Cary L. Cooper is the 5oth Anniversary Professor of Organisational Psychology and Health at the Alliance Manchester Business School, University of Manchester. He is president of the following organisations: CIPD, Relate, British Academy of Management and Institute of Welfare. He is also the author/editor of over 160 books and several hundred scholarly articles; the Editor-in-Chief of the Wiley-Blackwell Encyclopedia of Management (now in its 3rd edition), Founding Editor of the Journal of Organizational Behavior and co-editor of the Journal of Organizational Effectiveness. He received his CBE and Knighthood from the Queen for services to organisational health and the social sciences respectively in 2001 and 2014. 